\title{
The Ultimum Remedium Principle and Its Implementation on Tax Crime in Indonesia: a Case Study
}

\author{
Prianto Budi Saptono*, Cyntia Ayudia** \\ *Faculty of Administrative Sciences, Universitas Indonesia \\ ***Tax Researcher at KnDC Pratama-Kreston Tax Research Institute \\ DOI: 10.29322/IJSRP.11.01.2021.p10966 \\ http://dx.doi.org/10.29322/IJSRP.11.01.2021.p10966
}

\begin{abstract}
This study aims to analyze the implementation of the ultimum remedium principle on a case of tax crime in Indonesia based on the legal certainty principle in law enforcement. This research is descriptive, applying the case study method and using secondary data in documentary materials and library research. This study concludes that the tax auditor initially put forward criminal tax law enforcement rather than administrative tax law enforcement. The audit process does not reflect the legal certainty principle for taxpayers. The postponed examination became the preliminary evidence examination until the defendants' prosecution did not reflect the ultimum remedium principle's implementation. That ultimum remedium principle stipulates in Article 44B of the KUP Law (Law No. 28 of 2007).
\end{abstract}

Index Terms- ultimum remedium principle, tax law enforcement, certainty principle

\section{INTRODUCTION}

$\mathbf{I}^{\mathrm{n}}$ ndonesia's taxation system has two types of law enforcement, namely, administrative law and criminal law. The tax laws in Indonesia are part of the administrative law system. However, some of its provisions are relating to criminal law. In order for all state administrative provisions to be adequate, the development of a law enforcement policy is a necessity in the form of functionalizing criminal law aspects in administrative regulations to give rise to administrative penal law (Maroni, 2015, p. 23). According to Garner in Black's Law Dictionary (2009, p. 427), administrative crime is "an offense consisting of a violation of an administrative rule or regulation that carries with a criminal sanction."

The policy of including criminal sanctions in administrative law enforcement aims to create legal order and strengthen administrative sanctions. Logically, the application of criminal sanctions should apply if administrative sanctions are no longer effective (Sulaeman, 2014, p. 139; Maroni, 2015). However, criminal sanctions have various limitations and weaknesses, so the use or intervention of penalties should be carried out more cautiously, sparingly, selectively, and restrictively. It means not always using criminal sanctions in enforcing administrative law (Sulaeman, 2014, p. 139). Based on the two types of sanctions, Nils Jareborg (2005, p. 523) stipulated that criminalization should become the last resort (ultima ratio) in a series of law enforcement stages. This principle refers to "ultimum remedium" (p. 523).

However, in practice, in some instances, tax officers prefer to apply criminal sanctions to taxpayers by issuing preliminary investigation letter (also known as Surat Perintah Pemeriksaan Bukti Permulaan or "Sprinbukper"). The issuance of Sprinbukper refers to Article 43A of Law No. 28 of 2007 concerning General Provision and Tax Procedure (KUP Law). According to KUP Law, a preliminary investigation is an investigation conducted to obtain preliminary evidence on an alleged crime in the field of taxation. The provision authorizes the tax officers to examine preliminary evidence before investigating criminal offenses in the area of taxation. This evidence refers to information, data, reports, and complaints received by tax officers.

The above condition applies to a case we use as a case study in this research. The case study refers to a fiscal criminal case that ensnares a middle-level housing developer company in Central Java with its director and the director's attorney as tax crime perpetrators. The allegation stipulates in Article 39 of KUP Law. The allegations basis against both of them was because they had deliberately submitted a tax return or statement whose contents were incorrect or incomplete and did not pay taxes that had been withheld or collected. This study aims to analyze the implementation of the ultimum remedium principle stipulated under Article 44B of KUP Law. In this case, tax officers may issue Sprinbukper without issuing a tax audit letter (Surat Perintah Pemeriksaan or "SP2"), usually used to test taxpayers' compliance so that they seem not to apply the ultimum remedium principle.

With the description in the background above, there are 2 (two) problems which consist of:

1. How the ultimum remedium principle applied in this case study?

2. Is criminal law enforcement fulfill legal certainty? 


\section{CONCEPTUAL FRAMEWORK}

\section{A. Tax Law Enforcement}

The Rule of Law comprises several formal and procedural principles addressing how to govern society (Waldron, 2020). Thus the law must be enforced so that people could obey and behave according to the law. The United Kingdom calls it law enforcement, while the Netherlands calls it "rechtshandhaving" (Gunadi, 2017, p. 573). The tax laws in Indonesia are part of the administrative law system because it mainly regulates government administration. Indonesia's tax law regulates administrative sanctions in interest, fines, and increases to enforce the law. However, taxpayers tend to streamline the tax burden (Gunadi, 2017).

In order for all state administrative provisions to be adequate, the development of a law enforcement policy is necessary to functionalize criminal law and criminal procedure aspects in administrative regulations to give rise to administrative penal law (Maroni, 2015, p. 23). The criminal sanctions are in the form of confinement and imprisonment.

Garner (2009, p. 427) defines administrative crime as "an offense consisting of a violation of an administrative rule or regulation that carries with a criminal sanction." The policy of including criminal sanctions in administrative law enforcement aims to create legal order and strengthen administrative sanctions (Sulaeman, 2014, p. 139). Furthermore, administrative crime also optimizes tax compliance, prevents tax evasion, and maximizes state revenue.

\section{B. Ultimum Remedium Principle}

Criminal sanctions have various limitations and weaknesses, so the use or intervention of penalties should be carried out more cautiously, sparingly, selectively, and restrictively. It means not always using criminal sanctions in enforcing administrative law (Sulaeman, 2014, p. 139). In terms of the use of penal law, Nigel Walker (1980, p. 4) has formulated 'limiting principles' which state that "criminal law should not be used for certain purposes, or in certain circumstances." The 'limiting principle' includes the principle that the criminal law should not penalize behavior that does not harm. The use of criminal law must not be to achieve a purpose that can be achieved effectively at less cost in suffering (Walker, 1980, p. 5).

In tax crime, there is a legal principle known as "ultimum remedium." According to Nils Jareborg (2005, p. 523), criminalization must be the last resort (ultima ratio) in a series of law enforcement stages. As a Latin terminology, in Dutch, het laatste redmiddel or the last choice is also known as ultimum remedium. The ultimum remedium principle is a general principle inherent in the formal legal system of taxation throughout the world, both in countries adhering to the continental European legal system (civil law) and Anglo Saxon (common law). Unlike the Anti-Terrorism Law or the Anti-Corruption Law, which applies the "primum remedium" principle, the tax system intends to collect state revenue, not punish terrorists of corruptors (Kartanto, Rijadi, \& Priyati, 2020, p. 2). The implementation ultimum remedium principle has its justification and legitimacy.

The minimum criminalization principle agrees that criminal law must be limited to where alternative remedies are most effective and better condemn the perpetrator (Fedosiuk, 2012, p. 719). Maroni (2015, p. 132) defined the nature of the criminal sanctions as "ultimum remedium" (the last tool) to enforce tax collection. The ultimum remedium principle is the last measure in criminal law theory to determine what actions will lead to criminalization (Hasibuan, 2015, p. 118). Criminal sanctions are imposed on taxpayers when other legal instruments such as administrative law or civil law are insufficient (p. 124). Ultimum remedium implementation aims to ensure that victims and perpetrators of criminal acts receive justice in a relatively long criminal legal process and provide legal certainty.

\section{Legal Certainty Principle in Tax Law}

According to Adam Smith (1776, p. 718), the principle of legal certainty is a tax—which each individual is bound to pay—should be certain and not arbitrary. The timing of payment, payment method, and amount to be paid must all be clear to each person and every taxpayer (Smith, 1776; McLure, Charles E., 2019). Tax rules should be understandable, unambiguous, and specific so that taxpayers know where they stand (OECD, 2014, p. 30). Without clear guidelines, taxpayers will find it challenging to carry out their obligations and rights (Rosdiana \& Irianto, 2014, p. 168).

The certainty principle is inseparable from the law itself because the two are conceptually related (Bertea, 2008, p. 25). The certainty principle is part of the ease of administration and compliance principle criteria because it is related to the tax system and implementation (Wagner, 1883, p. 11; Seligman, 1920). Certainty in tax matters is an important objective. One practical tool to enhance tax certainty is dispute resolution mechanisms that should be fair and independent, accessible to taxpayers, and useful in resolving disputes promptly. To increase legal certainty, need detailed tax collection instructions, advanced rulings, and other legal interpretations (OECD, 2017, p. 7).

The criminal sanctions imposed on tax offenders in law enforcement of tax crime must justice values (Margono, 2020). Gustav Radbruch (2006, pp. 6-7) has proposed the concept of legal certainty is takes a curious middle place between the other two values, purposiveness and justice because it is required not only for the public benefit but also for justice. However, in addition to being fair, the tax enforcement must also fulfill the aspect of legal certainty principle. If there is a conflict between the value of justice and legal certainty, the value of legal certainty, secured by legislation and power, must take precedence even when its content of the law are unjust and fails to benefits the people. 


\section{RESEARCH METHOD}

This research is a qualitative one based on a case study method in line with Yin (2009) explanation. We used a case study because of having sufficient access to the potential data, in the form of reviewing documents or records or making observations in the field (Yin, 2009 , p. 26). This case study research refers to a tax crime case allegedly committed by a middle-level housing developer in Central Java. The case was still going on at the District Court in Central Java when we wrote this article.

\section{RESUlT AND DISCUSSION}

\section{A. The Implementation of Ultimum Remedium Principle}

In Indonesian tax legislation, tax officers have to prove suspicion of the taxpayers' incorrectness by examination and the presence of evidence related to not reported data in the Tax Return (Surat Pemberitahuan or "SPT"). Tax Return is the basis for starting an examination process as it contains a report of the tax calculation and payment within a certain tax period or a tax year. Tax officers must classify whether the phenomenon is an administrative violation or a tax crime (an act against tax law) based on audit findings. Also, it is necessary to separate whether a tax crime that causes losses to state revenue is negligence (Article 38 of the KUP Law) or intentional (Article 39 and Article 39A of the KUP Law) (Gunadi, 2017).

The case in this study constitutes a tax crime allegedly committed by a middle-level housing developer company in Central Java. The allegation refers to Article 39 paragraph (1) letter c, letter d, and letter i of KUP Law with its director and the director's attorney as tax crime perpetrators as quoted below:

"Article 39 paragraph (1):

Taxpayers are declared intentional if the taxpayer intentionally:

...

c. did not submit Tax Return;

d. submit Tax Return or information whose contents are incorrect or incomplete;

...

i. did not deposit taxes that have been deducted or collected.

It can cause a loss in state income, which is sentenced to a maximum of 6 (six) months imprisonment and a maximum of (six) years. Furthermore, the additional fine of at least 2 (two) times the amount of tax payable is unpaid or underpaid and a maximum of 4 (four) times the amount of unpaid or underpaid tax payable". (Law No. 28 of 2007)

The provisions above also apply to representatives, power of attorney, employees of taxpayers, or other parties who order to do, who participate in committing, who advocate, or who assist in committing criminal acts in the taxation field. In this case study, the allegations basis against both of them was because they had deliberately submitted a tax return or statement whose contents were untrue or incomplete and did not return taxes that had been withheld or collected. Determination of perpetrators refers to Article 43 paragraph (1) of KUP Law stipulates that a tax-criminal offense also applies to the taxpayers' representatives or authorities solely for accountability.

In this case study, tax officers have issued an audit letter (Surat Perintah Pemeriksaan or "SP2"). Tax officers conduct an examination of the company's Tax Return for the 2012 fiscal year. Based on Article 1, number 25 of KUP Law, the examination is an activity to collect data, information, or evidence carried out and process it objectively and professionally based on an examination standard. The examination process aims to test taxpayers' compliance with their obligations or for other purposes in implementing the tax laws and regulations.

Adequate examination criteria include completing the examination, disbursement of optimal examination results, and minimal remedies. For this reason, the completion of the examination must be within a certain period. The examination is complete if the tax auditor has made an audit letter and audit report (Laporan Hasil Pemeriksaan or "LHP"). The disbursement of tax assessments issued from the audit results must be reliable to achieve the target revenue from audits and minimize tax arrears.

However, there was a postpone of the examination process in this case study because tax officers apply criminal sanctions to taxpayers by issuing Sprinbukper refers to Article 43A of KUP Law in conjunction with Minister of Finance Regulation (Peraturan Menteri Keuangan or "PMK") No. 239/PMK.03/2014. Preliminary evidence is a condition, deed, and evidence in the form of information that can provide a clue that there is a strong allegation that a tax crime is being done or has been committed by anyone who can cause a loss in state income. A preliminary evidence investigation is an examination carried out to obtain Preliminary Evidence regarding an alleged tax crime. The preliminary evidence based on information, data, reports, and complaints (Informasi, Data, Laporan, dan Pengaduan or "IDLP") received by tax officers will be developed and analyzed through intelligence activities or observations.

Based on Article 3 paragraph 6 Director General of Tax Regulation (Peraturan Direktur Jenderal Pajak or "PER") No. 18/PJ/2014, one of the quality groups from the results of the development and analysis of IDLP is Group A, a namely strong indication that taxation has occurred. It is necessary to follow up Group A with the proposed preliminary investigation as stipulated in Article 3, paragraph 7 PER No. 18/PJ/2014. Therefore, criminal law enforcement proceeded to the prosecutorial stages up to imprisonment for both defendants in Central Java District Court.

Tax officers issue a preliminary investigation letter without issuing an audit report first. In this case, it is resulting in uncleanness in the application of the law. Following the audit standards in Indonesia, Article 10 of PMK No. 184/PMK.03/2015 states that tax auditors need to report audit activities to test taxpayers' compliance in the audit report (LHP). As a final product of the tax audit, an audit report

This publication is licensed under Creative Commons Attribution CC BY.

http://dx.doi.org/10.29322/IJSRP.11.01.2021.p10966

WWw.ijsrp.org 
must be concise and clear. An audit report should contain the scope and items examined for audit purposes. Also, it has to contain the tax auditor's conclusions supported by robust findings regarding the presence or absence of any tax regulations deviations and disclosure of other information related to the audit. An audit report is a basis for making the introductory calculation notes for notice of tax assessment and collection issuance.

Suppose it is an administrative violation, Tax Underpayment Assessment (Surat Keterangan Pajak Kurang Bayar or "SKPKB") can be issued plus administrative sanctions or an STP for administrative sanctions only. However, the taxpayer has the right to take legal remedies regarding disapproval of the amount from audit assessment through administrative measures, namely tax objection, appeal at the tax court, or judicial review at the Supreme Court.

On the other hand, if there are indications of a tax crime, according to explanatory memory of Articles 38 and 39 of KUP Law, submission of a Tax Return with incorrect or incomplete contents can depend on data and facts and evidence of findings can be corrected by the taxpayer, either on his own will or on an appeal from the tax office. Article 64 paragraph 1 PMK No. 184/PMK.03/2015 stipulates that the examination postponement becomes the preliminary evidence examination until the tax auditors conduct an investigation. The investigation can be stopped following Article 44B of the KUP Law not to require criminal effort. This regulation reflects that the implementation of penalties for violations of the law is not like primum remedium, but more oriented towards ultimum remedium principle.

Ultimum remedium is one of the principles in Indonesian criminal law that says that criminal law must be the last resort or final effort in law enforcement. It means that if a matter can take other lines (negotiation, meditation, or administrative law) should the passage be passed. About the ultimum remedium principle, Nigel Walker (1980, pp. 4-5) has formulated 'limiting principles' that state that "criminal law should not be used for certain purposes, or in certain circumstances." The 'limiting principle' includes the principle that the criminal law should not penalize behavior that does not harm. The use of criminal law should not be to achieve a purpose that can be achieved effectively at less cost in suffering. Criminal sanctions should apply if administrative sanctions are no longer effective (Sulaeman, 2014, p. 139; Maroni, 2015) or insufficient to achieve the public balance sheet straightening (Kartanto, Rijadi, \& Priyati, 2020).

Related to the ultimum remedium or primum remedium aspect, the provisions of tax legislation in KUP Law, Directorate General of Taxes (DGT), have a very extensive discourse about the criminal process in taxation violations. DGT has the authority to subjectively allow when to use the instrument of criminal sanctions or administrative sanctions. The preliminary investigation process based on Information, Data, Reports, and Complaints (IDLP) reflects the conditions that allow for such subjectivity. IDLP is entirely the authority of the DGT. From the IDLP Processing results, the DGT has the full discretion to choose to use administrative sanctions or criminal sanctions related to IDLP Processing results, which can harm the country's finances (Kartanto, Rijadi, \& Priyati, 2020).

Even though the taxpayer still has the right to disclose his actions, there is no explicit parameter for the taxpayer's disclosure results with the tax auditor's calculation, so there is legal uncertainty related to the disclosure of the untruth done by the taxpayer. Assembled by Article 44B of KUP Law, the Attorney General can stop the criminal offense investigation process based on the Minister of Finance's proposals as long as the court has not accepted the criminal case's delegation. In consideration of state revenue interests and as a technical rule of Article 44B of KUP Law, the Minister of Finance has issued a formula to resolve tax crime cases on PMK No. 130/PMK.03/2009. Through this regulation, taxpayers have the opportunity for the administrative resolution to stop the investigation process into tax crime cases. However, there is still compensation that must be paid by the taxpayer as a form of good faith. At this stage, if the General Attorney approves the request to stop the investigation, the taxpayer must submit a payment guarantee through an escrow account using a tax payment of underpaid tax with the additional administrative sanction of $400 \%$ (four hundred percent).

Reffering to Sarah Hasibuan's research in 2015 entitled "The Principle of Ultimum Remedium in the Application of Criminal Sanctions against Taxation Crimes by Taxpayers," concluded that the problem of Article 44B of the KUP Law by changing criminal sanctions with administrative sanctions could fulfill a sense of justice. The purpose of law is not solely for legal certainty but also to provide a sense of justice and benefit. The investigated taxpayers do not have to be delegated to court but given forgiveness as long as they pay the tax debt and its administrative penalties. Implementing the ultimum remedium principle in taxation provisions focuses on the priority scale to be aimed, namely more emphasis on optimizing state revenue, not on the criminal aspect.

The Panel of Judges, in their decision, believes that based on the ultimum remedium principle, the District Court is not authorized to handle this case because criminal law should be used as a last resort in law enforcement. Administrative sanctions must first address the norms or conventions in constitutional law and state administrative law, and civil law norms must first address the civil sanction. Administrative violations arise because of tax administrative procedures that taxpayers cannot heed in exercising tax rights and obligations. Violations of this type are subject to administrative sanctions, which can be in interest, fines, or increases. Suppose there is an underpayment of tax; the tax officers can issue a SKPKB. In the dispute regarding the difference in calculating the tax amount between the tax officers and taxpayers, it can be resolved administratively through sanctions or appeal mechanism.

Furthermore, as part of administrative law, tax law has very different interests from criminal law. In contrast, the straightforward tax issue to optimizing state revenue will become even more complicated when it is involved in the criminal realm. The taxation sector has its characteristics that cannot be compared with other methods of law enforcement. However, in this fiscal criminal case, the public prosecutor did not open taxpayers' opportunity to take the ultimum remedium as regulated in Article 44B of the KUP Law.

This publication is licensed under Creative Commons Attribution CC BY.

http://dx.doi.org/10.29322/IJSRP.11.01.2021.p10966

WWW.ijsrp.org 


\section{B. The Criminal Law Enforcement from Legal Certainty Perspective}

According to the Central Java District Court Decision, there is a lack of justice in applying the law. The Panel of Judges believes the tax officers allegation were incomplete and inaccurate because it does not formulate a method or measures before the investigation. As part of administrative law, tax regulation has very different interests from criminal law. The taxation sector has its characteristics that cannot be compared with other methods of law enforcement.

The absence of an Audit Result Report and facts regarding the IDLP reflect that the audit procedures are not transparent. In the context of transparency, the implementation of good governance principles should be following the principles of fair play and public trust in tax administration. The Tax Administration Law asks the tax office to fairly inform audit findings if there are calculations different from the Tax Return.

The law enforcement of tax crime and criminal sanctions imposed on tax offenders must reflect justice values (Margono, 2020). Gustav Radbruch (2006, pp. 6-7) has proposed the concept of legal certainty is takes a curious middle place between the other two values, purposiveness and justice, because it is required not only for the public benefit but also for justice. However, in addition to being fair, the tax enforcement must also fulfill the aspect of legal certainty principle. If there is a conflict between the value of justice and legal certainty, the value of legal certainty, secured by legislation and power, must take precedence even when its content of the law are unjust and fails to benefits the people.

According to McLure in The New Encyclopedia Britannica (2019) that "tax laws and regulations must be comprehensible to the taxpayer, they must be unambiguous and certain," both to the taxpayer and to the tax administrator. In line with the opinion of Adam Smith (Smith, 1776, p. 718) that taxes, which each individual is bound to pay, should be certain and not arbitrary. Without clear procedures, taxpayers will find it challenging to carry out their obligations and rights. It will be difficult for the tax authorities to oversee the implementation of tax obligations carried out by taxpayers and serve taxpayers' rights (Rosdiana and Irianto, 2014). Detailed tax collection instructions, advanced rulings, and other legal interpretations are needed to increase legal certainty.

Execution of audits that are not following the procedures as regulated in the law can create tax uncertainty. Do not let taxpayers be criminalized, even though they desire to comply with tax provisions by depositing and reporting taxes. After all, the purpose of taxes is not to imprison someone, but to increase state revenue.

\section{CONCLUSION}

This study on fiscal crime case studies that ensnare middle-level housing development companies in Central Java concludes that tax auditors prioritize criminal law enforcement's application over administrative law enforcement. The tax auditor suspends the examination to become a preliminary investigation based on Article 43A of the KUP Law, indicating a strong tax crime indicator. However, according to Article 64 paragraph 1 PMK No. 184/PMK.03/2015 stipulates that the examination postponement becomes the preliminary evidence examination until the tax officer conducts an investigation. The investigation can be stopped under Article 44B of the KUP Law, so there is no need to go through any criminal law enforcement. In this case study, the tax auditor did not take the ultimum remedium effort. An audit process that is not following the right procedure can cause legal uncertainty for taxpayers.

\section{REFERENCES}

[1] Bertea, S. (2008). Towards A New Paradigm of Legal Certainty. Legisprudence, Vol. 2, No. 1, 25-45.

[2] Fedosiuk, O. (2012). Criminal Liability as a Last Resort (Ultima Ratio): Theory and Reality. Jurisprudencija Vilnius, 19(2), 715-738.

[3] Garner, B. A. (2009). Black's Law Dictionary (9th ed.). United States of America: West Publishing Co.

[4] Gunadi. (2017). Panduan Komprehensif Ketentuan Umum Perpajakan (KUP). Jakarta: Bee Media Indonesia.

[5] Hasibuan, S. (2015). The Principle of Ultimum Remedium in the Application of Criminal Sanctions against Taxation Crimes by Taxpayer. USU Law Journal, 115-125.

[6] Jareborg, N. (2005). Criminalization as Last Resort (Ultima Ratio). Ohio State Journal of Criminal Law, $2,521-534$.

[7] Kartanto, L., Rijadi, P., \& Priyati, S. (2020). Quo Vadis Ultimum Remedium in Tax Criminal Crimes in Indonesia. International Journal of Scientific and Research Publication, 10(3).

[8] Margono, R. (2020). The Urgency of Asset Confiscation Sanction in Tax Crimes. International Journal of Research in Business and Social Science 9(5), $285-293$.

[9] Maroni. (2015). Pengantar Hukum Pidana Administrasi. Bandar Lampung: CV. Anugrah Utama Raharja (AURA).

[10] McLure, Charles E. (2019). Taxation. Retrieved from Encyclopaedia Britannica: https://www.britannica.com/topic/taxation

[11] OECD. (2014). Addressing The Tax Challenges of The Digital Economy.

[12] OECD. (2017). IMF/OECD Reports for the G20 Finance Ministers.

[13] Radbruch, G. (2006). Statutory Lawlessness and Supra-Statutory Law. Oxford Journal of Legal Studies, 26(1), 1-11.

[14] Rosdiana, H., \& Irianto, E. S. (2014). Pengantar Ilmu Pajak: Kebijakan dan Implementasi di Indonesia (3rd ed.). Jakarta: Rajawali Pers.



[16] Smith, A. (1776). An Inquiry into the Nature and Causes of the Wealth of Nations. Paris: Feedbooks.

[17] Sulaeman, E. (2014). Kebijakan Penggunaan Sanksi Pidana Dalam Perundang-undangan Hukum Administrasi. Wahana Akademika, 1(1), 135-148.

[18] Wagner, A. (1883). Three Extracts on Public Finance. In R. A. Musgrave, \& A. T. Peacock, Classics in the Theory of Public Finance (pp. 1-15). London: The Macmillan Press Ltd.

[19] Waldron, J. (2020). The Rule of Law. The Stanford Encyclopedia of Philosophy.

[20] Walker, N. (1980). Punishment, Danger and Stigma: The Morality of Criminal Justice. Totowa, New Jersey, United States of America: Barnes and Noble Books.

[21] Yin, R. K. (2009). Case Study Research Design and Methods (4th ed., Vol. 5). California: Sage Publications, Inc. 


\section{AUTHORS}

First Author - Dr. Prianto Budi Saptono, Lecturer, Universitas Indonesia, prianto.budi@gmail.com

Second Author - Cyntia Ayudia, Researcher, Pratama-Kreston Tax Research Institute, cyntia.ayudia@gmail.com

Correspondence Author - Prianto Budi Saptono, prianto.budi@gmail.com, +6281190618 